\title{
Risk of leakage with a new tissue containment system for power morcellation during gynecologic laparoscopy: An in vitro study
}

\section{Fang Zhao}

China-Japan Friendship Hospital https://orcid.org/0000-0002-7215-7280

Jing Liang ( $\sim$ jingliangzryhyy@163.com )

China-Japan Friendship Hospital https://orcid.org/0000-0001-7954-2889

\section{Bin Ling}

China-Japan Friendship Hospital

\section{Research Article}

Keywords: Laparoscopy, Power morcellation, Myomectomy, Tissue extraction

Posted Date: November 10th, 2021

DOl: https://doi.org/10.21203/rs.3.rs-697073/v1

License: (a) (i) This work is licensed under a Creative Commons Attribution 4.0 International License. Read Full License 


\section{Abstract \\ Purpose}

To evaluate leakage and tissue dissemination associated with a new tissue containment system for tissue removal during laparoscopic myomectomy morcellation using rigid pipes that can be seamlessly connected to detachable trocars.

\section{Methods}

Pork specimens were stained with indigo carmine dye and morcellated under laparoscopic guidance in a plastic trainer box. Morcellation was performed using two different containment systems. First, a polyurethane bag, $12 \mathrm{~mm}$ sheath for introduction into the peritoneal cavity, and $11 \mathrm{~mm}$ optic sleeve (control group). Second, a new tissue containment system using rigid pipes and detachable trocars (experimental group). All bags were inflated to $14-20 \mathrm{mmHg}$ pressure using a standard $\mathrm{CO} 2$ insufflator. Visual evidence of spilled tissue or dye and procedure times were recorded.

\section{Results}

Thirty trials were performed using a multi-port approach and the two tissue containment systems. The leakage rate was $0.03 \%$ for the experimental group and $26.6 \%$ for the control group $(p<0.005)$. Morcellation time was significantly shorter in the experimental group compared to that in the control group $(p<0.05)$. Mean bag introduction and removal times of the experimental group were shorter than those of the control group; however, the removal time differences were not statistically significant.

\section{Conclusion}

The current study quantified leakage during morcellation and the convenience provided by a new tissue containment system. Further studies and clinical trials are needed to corroborate the findings and to evaluate the use of the new tissue containment system for minimally invasive surgical treatment of tumors.

\section{Introduction}

During minimally invasive gynecologic surgery, extraction of large specimens is difficult. Accordingly, gynecologic surgeons usually use morcellators during laparoscopic and robotic-assisted supracervical hysterectomies and myomectomies. However, morcellation may result in the disruption and/or dissemination of tissue. There is particular concern regarding the spread of morcellated tissue fragments in cases of occult malignancy [1-10]. The US Food and Drug Administration (FDA) issued a safety communication in April 2014, discouraging the use of laparoscopic power morcellation during 
hysterectomy or myomectomy to treat uterine myomas [11]. In 2020, the FDA recommended performing laparoscopic power morcellation for myomectomy or hysterectomy with a tissue containment system [12]. Since then, various tissue containment systems have been developed and studies related to their use have been conducted. Our current research was performed to assess the potential of leakage and convenience of use for a new tissue containment system.

\section{Materials And Methods}

\section{Materials}

The new tissue containment system in our study had three unique advantages. First, a rigid pipe was used to reduce puncture leakage during penetration of the abdominal wall. Second, the trocar could be tightly connected to the pipe to form a sealed space for power morcellation. Third, hard pipes were more convenient than soft bags in regards to removal from the abdominal cavity without leakage.

\section{Methods}

The current investigation was a pilot study performed at an academic hospital laparoscopic skills laboratory. The study design used pork specimens and an enclosed laparoscopic trainer box to simulate laparoscopic power morcellation during hysterectomy or myomectomy. The trainer boxes were covered with a $2 \mathrm{~cm}$ thick silica gel to simulate the abdominal wall (Fig. 1). The pork specimens were cut to a weight of $400 \mathrm{~g}$, placed in the tissue containment system, and dyed using $5 \mathrm{~mL}$ methylene blue solution (Fig. 1b). The dye was added to aid in the detection of leakage. Two different tissue containment systems were evaluated. The new tissue containment system included hard pipes that could be connected to detachable trocars and was considered the "experimental group" (Fig. 2). The second system was a poly urethane bag, $12 \mathrm{~mm}$ sheath for its introduction into the peritoneal cavity, and an $11 \mathrm{~mm}$ optic sleeve and was considered the "control group" (Fig. 3). Thirty trials were performed using each of the two tissue containment systems with a multi-port approach. All physicians who participated in the study were gynecologic surgeons experienced at performing minimally invasive surgeries. Individual surgeons were randomly assigned to the experimental or control groups and all trials were monitored by a senior surgeon.

When using the experimental device, the tissue containment system was inserted into the abdominal cavity of the training box via the right lateral access with the aid of a $15 \mathrm{~mm}$ introduction sheath. Once the specimen was positioned in the tissue containment system, the two hard pipes were passed out through the umbilical and the left accesses, respectively, and connected to the trocar. The trocar inlet hole was used to inflate the bag. To assist with morcellation, a monitoring mirror was placed through the umbilical trocar and a forceps was placed on the left trocar. The right opening of the bag was used for access of the morcellator. The specimen was entirety morcellated under monitoring (Fig. 2b). Upon completion of the morcellation, the monitoring mirror and forceps were removed after deflation of the bag 
and the two hard pipes were covered with caps. Finally, the tissue containment system was removed via the right lateral access of the trainer box.

In the control group, the bag was inserted into the abdominal cavity of the training box via the lateral access with the help of a $10 \mathrm{~mm}$ introduction sheath. The specimen was then positioned into the bag via its large opening. Once the specimen was positioned in the bag, both openings of the bag needed to be exteriorized for optic and morcellator access. The optical trocar was then removed and re-inserted into the bag via the tubular bag opening through the umbilical access. A pseudo-pneumoperitoneum was established by inflating the bag via the umbilical trocar. After completing the morcellation, the optics were withdrawn from the bag. The everted tubular portion of the bag at the umbilical site was closed with two knots. Finally, the entire bag was removed by manually pulling it through the lateral side.

After removal of the tissue containment systems, the trainer boxes were examined for the presence of any dye (Fig. 4). The systems were then filled with $1000 \mathrm{~mL}$ saline to confirm the absence of damage (Fig. 5). Finally, each sheath was washed with cell culture solution and the solution evaluated for cytologic evidence to identify whether there were any muscle fragments present. The cytologic findings were obtained using an Auto Cycle Prep 2002 instrument (Becton, Dickinson and Company). Any positive cytologic results were considered to have resulted from leakage during the laparoscopic procedure.

The primary outcomes were (i) leakage rates, (ii) bag introduction time (time from bag insertion to start of abdominal insufflation and morcellation), (iii) bag removal time (time to remove the bag from the body and resume intraperitoneal observation), and (iv) in-bag morcellation time. Statistical analyses were performed using GraphPad software and included descriptive calculations of the mean and standard deviation (SD), 95\% confidence interval (Cl), median, and minimum-to-maximum range. Unrelated continuous data from the two study groups were compared using an unpaired t-test at a significance level of $p \leq 0.05$. Categorical data were compared in a contingency table and analyzed using Fisher's exact test for significance at a level of $p \leq 0.05$.

\section{Results}




\section{Contained Tissue Extraction}

\section{Experimental Group}

Trial Trainer Box

\#

Visual

Inspection

$\begin{array}{ll}\text { Trial } & \text { Several } \\ 1 & \text { drops of } \\ & \text { blue dye }\end{array}$

Trial Clean, no Intact

2 tissue chip

Trial Clean, no Intact

3 tissue chip

Trial Clean, no Intact

$4 \quad$ tissue chip

Trial Clean, no Intact

5 tissue chip

Trial Clean, no Intact

6 tissue chip

Intact

ntact

\section{Bag \\ Visual \\ Cytologic
Findings}

Inspection

Negative

Negative

Negative

.

Negative

Negative

Negative

Control Group

$\begin{array}{llll}\text { Trial } & \text { Trainer Box } & \text { Bag } & \text { Cytologic } \\ \# & \text { Visual } & \text { Visual } & \text { Findings } \\ & \text { Inspection } & \text { Inspection } & \end{array}$

Trial Clean, no Intact Negative

1 tissue chip

Intact

tissue chip

2 tissue chip

Trial Clean, no Intact Negative

3 tissue chip

Trial Several Intact Negative

4 drops of

blue dye

Trial Clean, no Intact Negative

5 tissue chip

Trial Clean, no broken Positive

6 tissue chip for

muscle

fragments

$\begin{array}{llllllll}\begin{array}{l}\text { Trial } \\ 7\end{array} & \begin{array}{l}\text { Clean, no } \\ \text { tissue chip }\end{array} & \text { Intact } & \text { Negative } & \begin{array}{l}\text { Trial } \\ 7\end{array} & \begin{array}{l}\text { Clean, no } \\ \text { tissue chip }\end{array} & \text { Intact } & \text { Negative } \\ \begin{array}{l}\text { Trial } \\ 8\end{array} & \begin{array}{l}\text { Clean, no } \\ \text { tissue chip }\end{array} & \text { Intact } & \text { Negative } & \begin{array}{l}\text { Trial } \\ 8\end{array} & \begin{array}{l}\text { Clean, no } \\ \text { tissue chip }\end{array} & \text { Intact } & \text { Negative } \\ \begin{array}{l}\text { Trial } \\ 9\end{array} & \begin{array}{l}\text { Clean, no } \\ \text { tissue chip }\end{array} & \text { Intact } & \text { Negative } & \begin{array}{l}\text { Trial } \\ 9\end{array} & \begin{array}{l}\text { Several } \\ \text { drops of } \\ \text { blue dye }\end{array} & \text { Intact } & \begin{array}{l}\text { Positive } \\ \text { for } \\ \text { muscle }\end{array}\end{array}$

fragments

$\begin{array}{llllllll}\begin{array}{l}\text { Trial } \\ 10\end{array} & \begin{array}{l}\text { Clean, no } \\ \text { tissue chip }\end{array} & \text { Intact } & \text { Negative } & \begin{array}{l}\text { Trial } \\ 10\end{array} & \begin{array}{l}\text { Clean, no } \\ \text { tissue chip }\end{array} & \text { Intact } & \text { Negative } \\ \begin{array}{l}\text { Trial } \\ 11\end{array} & \begin{array}{l}\text { Clean, no } \\ \text { tissue chip }\end{array} & \text { Intact } & \text { Negative } & \begin{array}{l}\text { Trial } \\ 11\end{array} & \begin{array}{l}\text { Clean, no } \\ \text { tissue chip }\end{array} & \text { Intact } & \text { Negative } \\ \begin{array}{l}\text { Trial } \\ 12\end{array} & \begin{array}{l}\text { Clean, no } \\ \text { tissue chip }\end{array} & \text { Intact } & \text { Negative } & \begin{array}{l}\text { Trial } \\ 12\end{array} & \begin{array}{l}\text { Clean, no } \\ \text { tissue chip }\end{array} & \text { Intact } & \text { Negative } \\ \begin{array}{l}\text { Trial } \\ 13\end{array} & \begin{array}{l}\text { Clean, no } \\ \text { tissue chip }\end{array} & \text { Intact } & \text { Negative } & \begin{array}{l}\text { Trial } \\ 13\end{array} & \begin{array}{l}\text { Several } \\ \text { drops of } \\ \text { blue dye }\end{array} & \text { Intact } & \begin{array}{l}\text { Positive } \\ \text { for } \\ \text { muscle }\end{array} \\ & & & & & & \text { fragments } \\ \end{array}$




\section{Contained Tissue Extraction}

\begin{tabular}{|c|c|c|c|c|c|c|c|}
\hline $\begin{array}{l}\text { Trial } \\
14\end{array}$ & $\begin{array}{l}\text { Clean, no } \\
\text { tissue chip }\end{array}$ & Intact & Negative & $\begin{array}{l}\text { Trial } \\
14\end{array}$ & $\begin{array}{l}\text { Several } \\
\text { drops of } \\
\text { blue dye }\end{array}$ & Intact & Negative \\
\hline $\begin{array}{l}\text { Trial } \\
15\end{array}$ & $\begin{array}{l}\text { Clean, no } \\
\text { tissue chip }\end{array}$ & Intact & Negative & $\begin{array}{l}\text { Trial } \\
15\end{array}$ & $\begin{array}{l}\text { Clean, no } \\
\text { tissue chip }\end{array}$ & Intact & Negative \\
\hline $\begin{array}{l}\text { Trial } \\
16\end{array}$ & $\begin{array}{l}\text { Clean, no } \\
\text { tissue chip }\end{array}$ & Intact & Negative & $\begin{array}{l}\text { Trial } \\
16\end{array}$ & $\begin{array}{l}\text { Clean, no } \\
\text { tissue chip }\end{array}$ & Intact & Negative \\
\hline $\begin{array}{l}\text { Trial } \\
17\end{array}$ & $\begin{array}{l}\text { Clean, no } \\
\text { tissue chip }\end{array}$ & Intact & Negative & $\begin{array}{l}\text { Trial } \\
17\end{array}$ & $\begin{array}{l}\text { Clean, no } \\
\text { tissue chip }\end{array}$ & Intact & Negative \\
\hline \multirow[t]{2}{*}{$\begin{array}{l}\text { Trial } \\
18\end{array}$} & $\begin{array}{l}\text { Clean, no } \\
\text { tissue chip }\end{array}$ & Intact & Negative & $\begin{array}{l}\text { Trial } \\
18\end{array}$ & $\begin{array}{l}\text { Several } \\
\text { drops of } \\
\text { blue dye }\end{array}$ & Intact & $\begin{array}{l}\text { Positive } \\
\text { for } \\
\text { muscle }\end{array}$ \\
\hline & & & & & & & fragments \\
\hline $\begin{array}{l}\text { Trial } \\
19\end{array}$ & $\begin{array}{l}\text { Clean, no } \\
\text { tissue chip }\end{array}$ & Intact & Negative & $\begin{array}{l}\text { Trial } \\
19\end{array}$ & $\begin{array}{l}\text { Clean, no } \\
\text { tissue chip }\end{array}$ & broken & Negative \\
\hline $\begin{array}{l}\text { Trial } \\
20\end{array}$ & $\begin{array}{l}\text { Clean, no } \\
\text { tissue chip }\end{array}$ & Intact & Negative & $\begin{array}{l}\text { Trial } \\
20\end{array}$ & $\begin{array}{l}\text { Clean, no } \\
\text { tissue chip }\end{array}$ & Intact & Negative \\
\hline $\begin{array}{l}\text { Trial } \\
21\end{array}$ & $\begin{array}{l}\text { Clean, no } \\
\text { tissue chip }\end{array}$ & Intact & Negative & $\begin{array}{l}\text { Trial } \\
21\end{array}$ & $\begin{array}{l}\text { Clean, no } \\
\text { tissue chip }\end{array}$ & Intact & Negative \\
\hline $\begin{array}{l}\text { Trial } \\
22\end{array}$ & $\begin{array}{l}\text { Clean, no } \\
\text { tissue chip }\end{array}$ & Intact & Negative & $\begin{array}{l}\text { Trial } \\
22\end{array}$ & $\begin{array}{l}\text { Clean, no } \\
\text { tissue chip }\end{array}$ & Intact & Negative \\
\hline $\begin{array}{l}\text { Trial } \\
23\end{array}$ & $\begin{array}{l}\text { Clean, no } \\
\text { tissue chip }\end{array}$ & Intact & Negative & $\begin{array}{l}\text { Trial } \\
23\end{array}$ & $\begin{array}{l}\text { Clean, no } \\
\text { tissue chip }\end{array}$ & Intact & Negative \\
\hline $\begin{array}{l}\text { Trial } \\
24\end{array}$ & $\begin{array}{l}\text { Clean, no } \\
\text { tissue chip }\end{array}$ & Intact & Negative & $\begin{array}{l}\text { Trial } \\
24\end{array}$ & $\begin{array}{l}\text { Clean, no } \\
\text { tissue chip }\end{array}$ & Intact & Negative \\
\hline $\begin{array}{l}\text { Trial } \\
25\end{array}$ & $\begin{array}{l}\text { Clean, no } \\
\text { tissue chip }\end{array}$ & Intact & Negative & $\begin{array}{l}\text { Trial } \\
25\end{array}$ & $\begin{array}{l}\text { Clean, no } \\
\text { tissue chip }\end{array}$ & Intact & Negative \\
\hline $\begin{array}{l}\text { Trial } \\
26\end{array}$ & $\begin{array}{l}\text { Clean, no } \\
\text { tissue chip }\end{array}$ & Intact & Negative & $\begin{array}{l}\text { Trial } \\
26\end{array}$ & $\begin{array}{l}\text { Clean, no } \\
\text { tissue chip }\end{array}$ & Intact & Negative \\
\hline \multirow[t]{2}{*}{$\begin{array}{l}\text { Trial } \\
27\end{array}$} & $\begin{array}{l}\text { Clean, no } \\
\text { tissue chip }\end{array}$ & Intact & Negative & $\begin{array}{l}\text { Trial } \\
27\end{array}$ & $\begin{array}{l}\text { Several } \\
\text { drops of } \\
\text { blue dye }\end{array}$ & Intact & $\begin{array}{l}\text { Positive } \\
\text { for } \\
\text { muscle }\end{array}$ \\
\hline & & & & & & & fragments \\
\hline $\begin{array}{l}\text { Trial } \\
28\end{array}$ & $\begin{array}{l}\text { Clean, no } \\
\text { tissue chip }\end{array}$ & Intact & Negative & $\begin{array}{l}\text { Trial } \\
28\end{array}$ & $\begin{array}{l}\text { Clean, no } \\
\text { tissue chip }\end{array}$ & Intact & Negative \\
\hline $\begin{array}{l}\text { Trial } \\
29\end{array}$ & $\begin{array}{l}\text { Clean, no } \\
\text { tissue chip }\end{array}$ & Intact & Negative & $\begin{array}{l}\text { Trial } \\
29\end{array}$ & $\begin{array}{l}\text { Clean, no } \\
\text { tissue chip }\end{array}$ & Intact & Negative \\
\hline
\end{tabular}




\section{Contained Tissue Extraction}

\begin{tabular}{|c|c|c|c|c|c|c|}
\hline $\begin{array}{l}\text { Trial } \\
30\end{array}$ & $\begin{array}{l}\text { Clean, no } \\
\text { tissue chip }\end{array}$ & Intact & Negative & $\begin{array}{l}\text { Trial } \\
30\end{array}$ & $\begin{array}{l}\text { Several } \\
\text { drops of } \\
\text { blue dye }\end{array}$ & Intact \\
\hline
\end{tabular}

Table 2

Contained Tissue Extraction

\begin{tabular}{|c|c|c|c|}
\hline & Experimental Group & Control Group & $\begin{array}{l}p- \\
\text { value* }\end{array}$ \\
\hline $\begin{array}{l}\text { Bag Introduction } \\
\text { Time }\end{array}$ & $\begin{array}{l}7.56 \text { min (range, 5-11 } \\
\text { min) }\end{array}$ & $\begin{array}{l}10.33 \text { min (range, } 9-13 \\
\text { min) }\end{array}$ & $<0.001$ \\
\hline $\begin{array}{l}\text { In-Bag Morcellation } \\
\text { Time }^{\text {a }}\end{array}$ & $\begin{array}{l}9.9 \min \text { (range, } 9-11 \\
\min )\end{array}$ & $\begin{array}{l}14.11 \text { min (range, } 10-16 \\
\text { min) }\end{array}$ & 0.003 \\
\hline Bag Removal Time & $\begin{array}{l}2.11 \text { min (range, } 1.5-2.5 \\
\text { min) }\end{array}$ & $\begin{array}{l}2.20 \text { min (range, } 2-3 \\
\text { min) }\end{array}$ & 0.147 \\
\hline Leakage Rate & $3.3 \%$ & $26.6 \%$ & 0.026 \\
\hline
\end{tabular}

\section{Discussion}

The US FDA issued a safety communication in April 2014, discouraging the use of laparoscopic power morcellation during hysterectomy or myomectomy to treat uterine myomas [11]. Subsequently, various tissue containment systems have been developed and studies related to their use have been conducted. In 2014, Cohen et al. [13] demonstrated for both single-site and multi-port techniques that use of a 1-piece isolation bag can successfully contain tissue during the morcellation process. These investigators reported a single puncture site in 13 trials when using a stitch-sealed bag [13]. However, they were unable to determine whether these results would reproducibly occur under repeated trials using this type of stitchsealed bag. In 2015, Rimbac and colleagues proved the technical feasibility and safety of an in-bag morcellation system in a clinical setting during laparoscopic hysterectomy. Of the six bags used during the procedures, two developed tiny leaks at the site of the optic trocar insertion [14]. This shows that most leakage occurred during manipulation of the bag for insertion. A subsequent prospective in vivo study reported spillage in 7 of 76 cases (9.2\%) [15]. In one case, a containment bag tear was noted prior to morcellation due to manipulation of the bag during insertion. In another case, a tear was created during removal of the containment bag.

Based on the above cited research, we believe that leakage during the use of tissue containment systems mainly occurs in the course of optic trocar insertion and during removal of the bag. Owing to the material used to produce the bag, it can be easily damaged during installation and may be pierced in the everted tubular portion when the morcellator repeatedly enters the opening of the bag. When the tissue 
containment system is removed, tissue fragments can enter the abdominal cavity through the puncture. Therefore, after a significant amount of refinement, we developed a new tissue containment system, which includes rigid pipes that can be connected to detachable trocars. In our current study, the experimental group in which the trocars were connected to the pipes demonstrated a reduced rate of leakage during the process of the morcellator entering the opening of the bag $(p<0.005)$. The rigid pipes were sealed with caps when removed from the abdominal cavity, which prevented any excised tissue being discharged from the bag and back into the abdominal cavity. In our study, we used three methods to monitor for leakage; any one positive result was considered a leak had occurred. The leakage rate was $0.03 \%$ in the experimental group and $26.6 \%$ in the control group $(p<0.005)$. In the only case of leakage in the experimental group, the leakage occurred when the gas had not been completely discharged during bag removal. In all subsequent experiments, when the gas was completely discharged before the bag body was removed, no leakage occurred.

In a study by Devassy et al., the mean time of bag manipulation was approximately 7 min and the mean morcellation time was 12 min [16]. In our current study, the bag manipulation time of the experimental group was similar to that reported previously. However, the morcellation time was significantly shorter for the experimental group than that of the control group $(p<0.05)$. This may have been due to the addition of the two rigid pipes to the design of the system, one of which was used for placing the optical trocar and the other used to assist with the morcellation instrument. This was able to significantly shorten the morcellation time. The mean bag introduction time and removal time of the experimental group were shorter than those of the control group. However, while the removal time tended to be shorter for the experimental group, the difference failed to reach statistical significance. We believe the rigid pipe being made of a hard material resulted in it being easier to insert and remove the containment bag through the operating hole compared to that of a soft bag alone, thereby greatly shortening the time required for bag manipulation and removal.

\section{Conclusions}

In our in vitro study of a new tissue containment system, we found the new system was easier to operate during laparoscopic gynecological tumor surgery compared to that of the control containment system and it exhibited a lower rate of leakage. However, prospective clinical studies with larger cohorts of patients are necessary to confirm the efficiency of the bags in routine use during laparoscopic morcellation.

\section{Declaration}

\section{Conflicts of interest}

There are no conflicts of interest to declare.

\section{References}


1. Lieng M, Istre O, Busund B, Qvigstad E (2006) Severe complications caused by retained tissue in laparoscopic supracervical hysterectomy. J Minim Invas Gynecol 13:231-233.

DOI:10.1016/j.jmig.2006.01.006

2. Hutchins FL Jr, Reinoehl EM (1998) Retained myoma after laparoscopic supracervical 281 hysterectomy with morcellation. J Am Assoc Gynecol Laparosc 5:293-295. DOI:10.1016/s10743804(98)80035-2

3. Cucinella G, Granese R, Calagna G, Somigliana E, Perino A (2011) Parasitic myomas after laparoscopic surgery: an emerging complication in the use of morcellator? Description of four cases. Fertil Steril 96:e90-e96. DOI:10.1016/j.fertnstert.2011.05.095

4. Leren V, Langebrekke A, Qvigstad E (2012) Parasitic leiomyomas after laparoscopic surgery with morcellation. Acta Obstet Gynecol Scand 91:1233-1236. DOI:10.1111/j.1600-0412.2012.01453.x

5. Turner T, Secord AA, Lowery WJ, Sfakianos G, Lee PS (2013) Metastatic adenocarcinoma after laparoscopic supracervical hysterectomy with morcellation: A case report. Gynecol Oncol Case Rep 5:19-21. DOI:10.1016/j.gynor.2013.03.002

6. Della Badia C, Karini H (2010) Endometrial stromal sarcoma diagnosed after uterine morcellation in laparoscopic supracervical hysterectomy. J Minim Invasive Gynecol 17:791-793.

DOI:10.1016/j.jmig.2010.07.001

7. Anupama R, Ahmad SZ, Kuriakose S, Vijaykumar DK, Pavithran K (2011) Seethalekshmy NV Disseminated peritoneal leiomyosarcomas after laparoscopic "myomectomy" and morcellation. J Min Invas Gynecol 18:386-389

8. Oduyebo T, Rauh-Hain AJ, Meserve EE, Seidman MA, Hinchcliff E, George S, Quade B, Nucci MR, Del Carmen MG, Muto MG (2014) The value of re-exploration in patients with inadvertently morcellated uterine sarcoma. Gynecol Oncol 132:360-365 DOI: 10.1016/j.ygyno.2013.11.024, pii: S00908258(13)01351-6

9. Seidman MA, Oduyebo T, Muto MG, Crum CP, Nucci MR, Quade BJ (2012) Peritoneal dissemination complicating morcellation of uterine mesenchymal neoplasms. PLOS ONE 7:e50058. DOI:10.1371/journal.pone.0050058

10. Park JY, Park SK, Kim DY, Kim JH, Kim YM, Kim YT, Nam JH (2011) The impact of tumor morcellation during surgery on the prognosis of patients with apparently early uterine leiomyosarcoma. Gynecol Oncol 122:255-259. DOI:10.1016/j.ygyno.2011.04.021

11. US Food and Drug Administration Laparoscopic uterine power morcellation in hysterectomy and myomectomy: FDA safety communication.

http://www.fda.gov/MedicalDevices/Safety/AlertsandNotices/ucm393576.htm. Accessed May 12, 2014

12. UPDATE The FDA recommends performing contained morcellation in women when laparoscopic powermorcellation is appropriate https://www.fda.gov/medical-devices/safetycommunications/update-fda-recommends-performing-contained-morcellation-women-whenlaparoscopic-power-morcellation Accessed Febr 25, 2020 
13. Cohen SL, Greenberg JA, Wang KC, Srouji SS, Gargiulo AR, Pozner CN, Hoover N, Einarsson JI (2014) Risk of leakage and tissue dissemination with various contained tissue extraction (CTE) techniques: an in vitro pilot study. J Minim Invas Gynecol 21:935-939. DOl:10.1016/j.jmig.2014.06.004

14. Rimbach S, Holzknecht A, Schmedler C, Nemes C, Offner F (2016) First clinical experiences using a new in-bag morcellation system during laparoscopic hysterectomy. Arch Gynecol Obstet 294:83-93. DOI:10.1007/s00404-015-3986-5

15. Cohen SL, Morris SN, Brown DN, Greenberg JA, Walsh BW, Gargiulo AR, Isaacson KB, Wright KN, Srouji SS, Anchan RM, Vogell AB, Einarsson JI (2016) Contained tissue extraction using power morcellation: prospective evaluation of leakage parameters. Am J Obstet Gynecol 214:257.e1257.e6. DOI:10.1016/j.ajog.2015.08.076

16. Rajesh D, Cristina C, Harald K et al (2019) Feasibility of myomatous tissue extraction in laparoscopic surgery by contained in - bag morcellation: A retrospective single arm study. Int J Surg 62:22-27

\section{Figures}

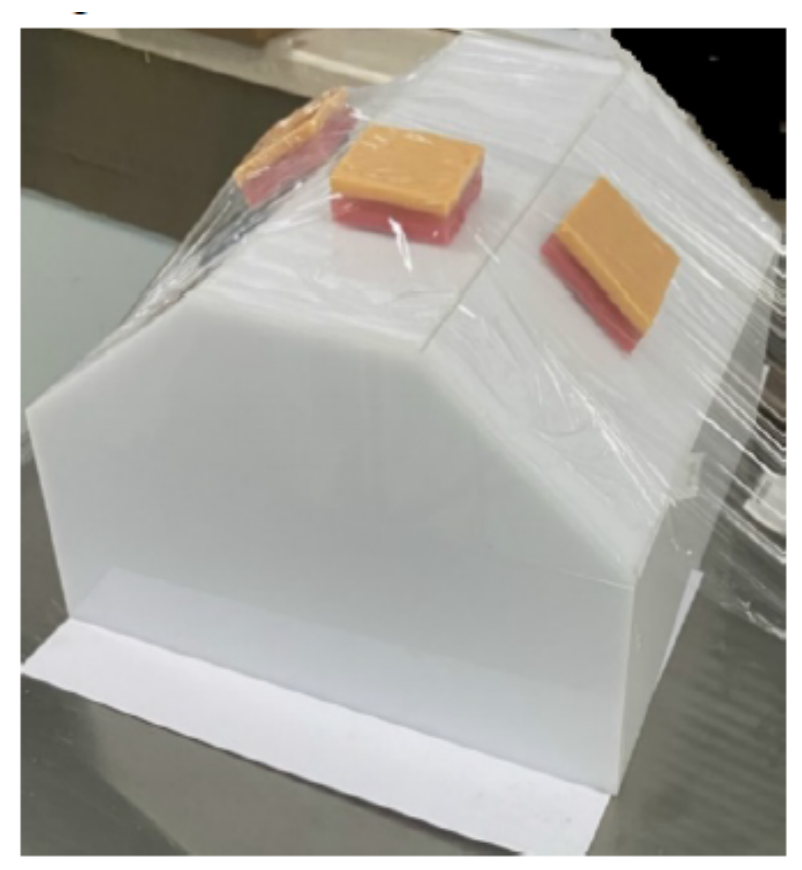

A

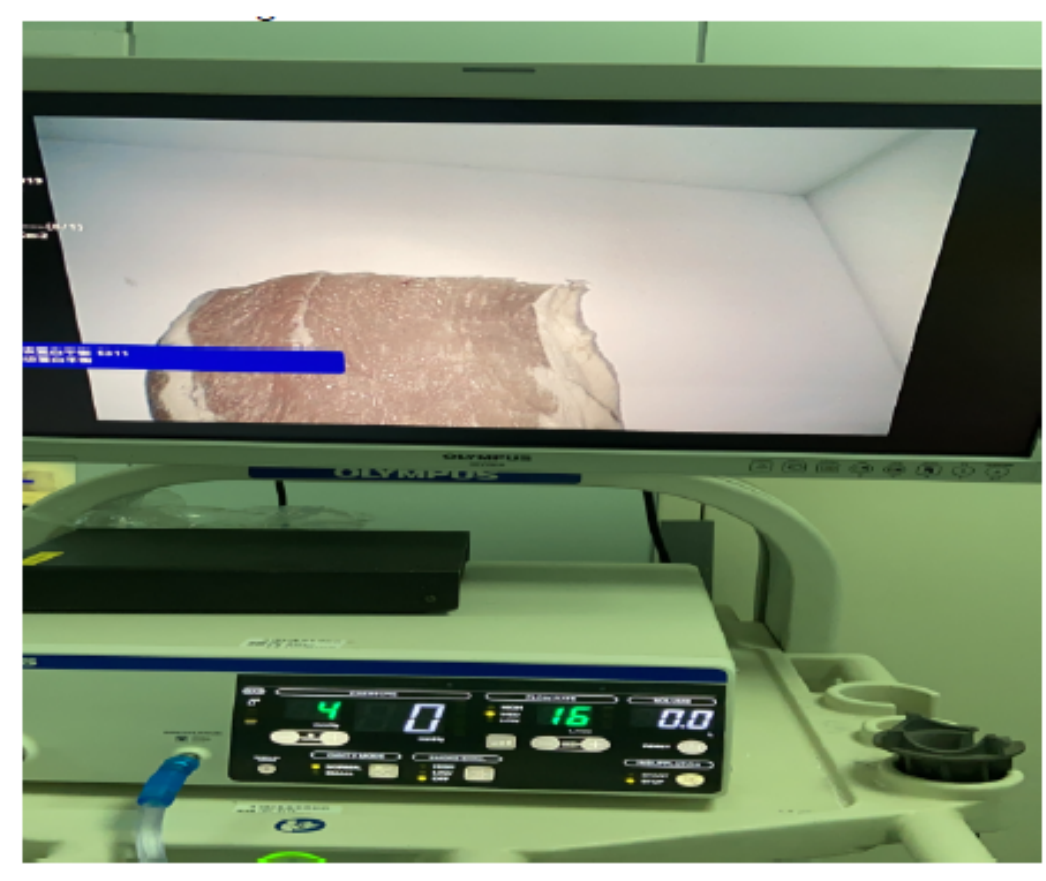

B

\section{Figure 1}

Legend not included with this version. 


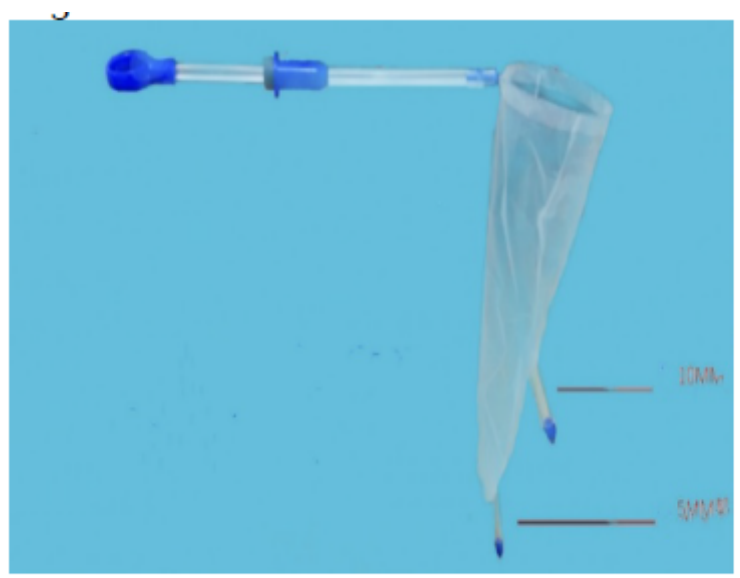

A

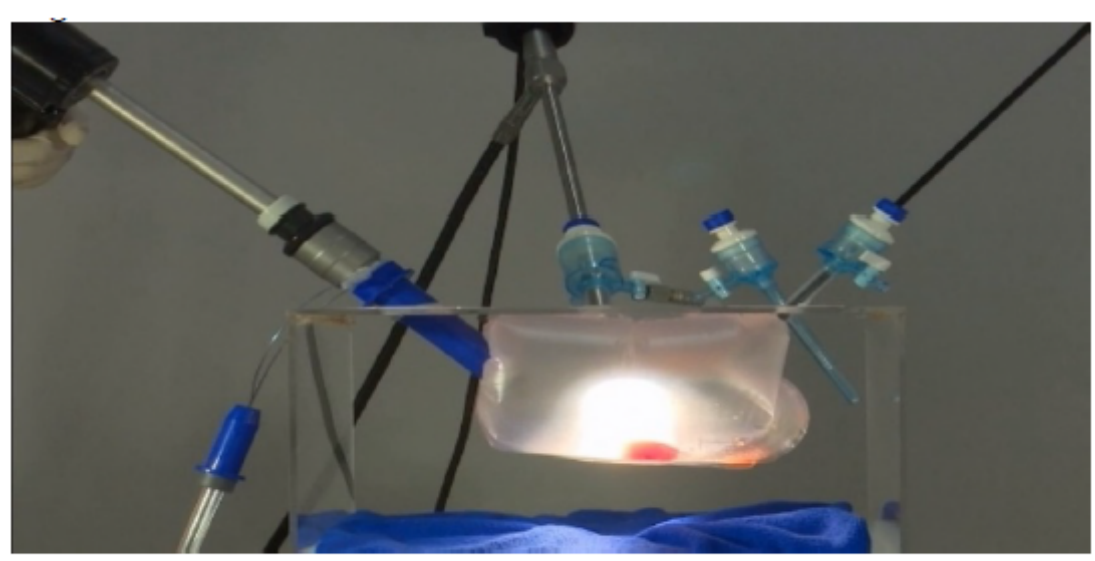

B

Figure 2

Legend not included with this version.

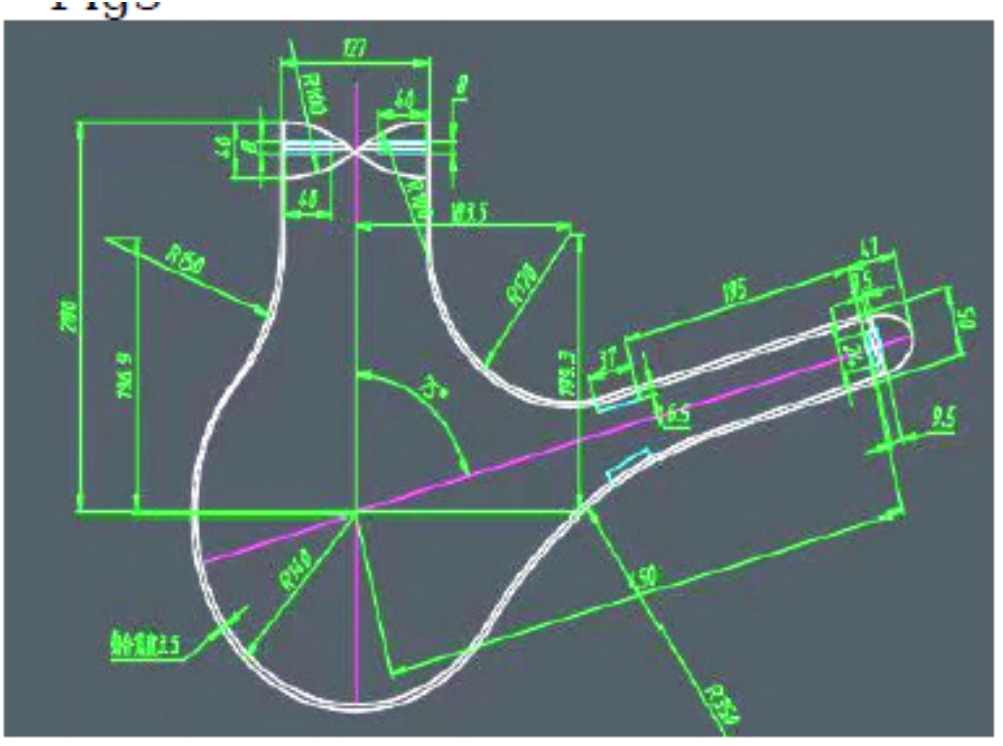

Figure 3

Legend not included with this version.

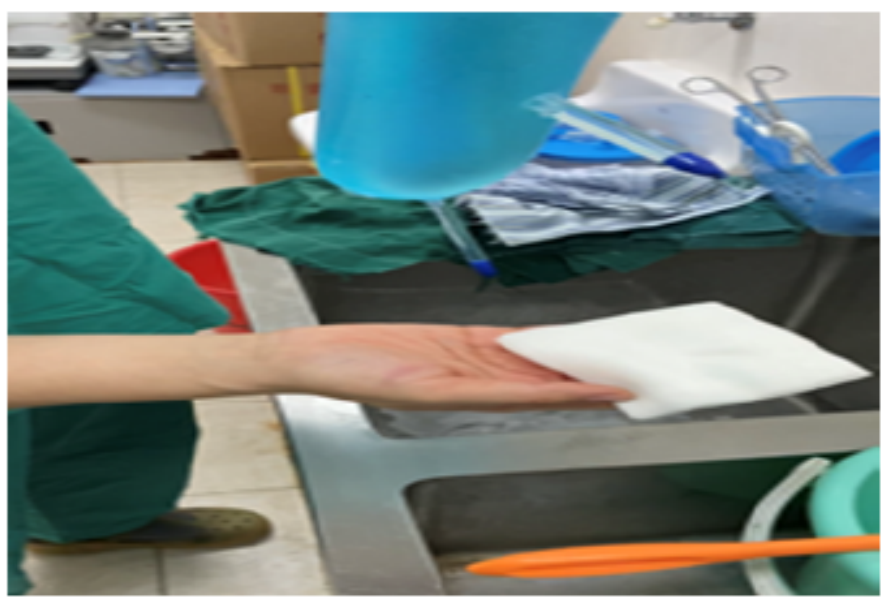


Figure 4

Legend not included with this version.

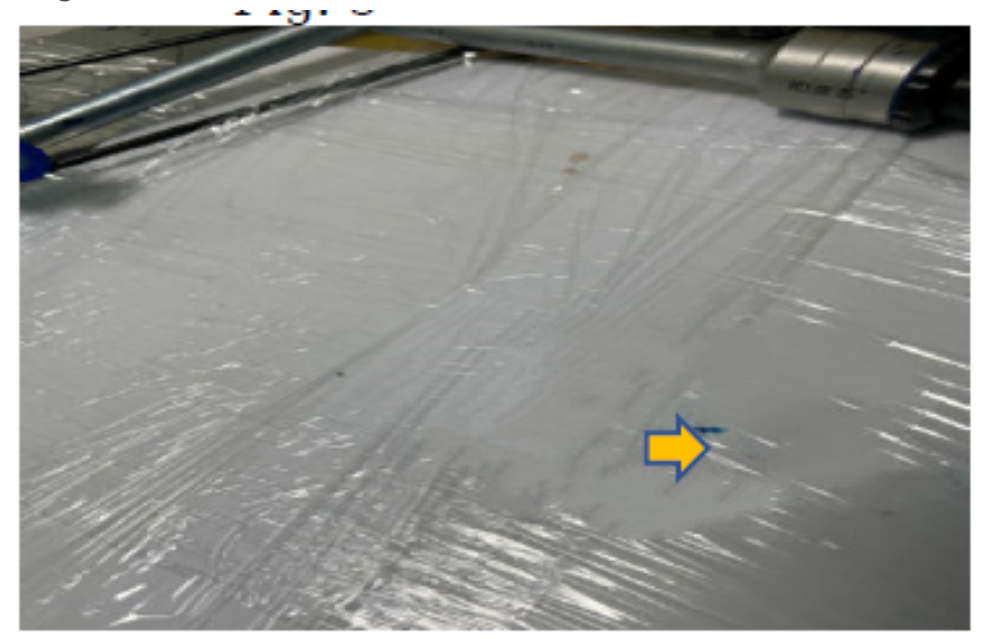

Figure 5

Legend not included with this version. 